\title{
MICROBIOLOGICAL STUDIES OF THE CREAM FOR USE IN THE DIABETIC FOOT SYNDROME
}

\author{
A.A.Goncharova, I.I.Baranova, T.P.Osolodchenko \\ National University of Pharmacy \\ State Institution "Institute of Microbiology and Immunology named after I.I.Mechnikov \\ of the National Academy of Medical Sciences of Ukraine"
}

Key words: tea tree oil; preservative; microbiological stability; microbiological research; diabetic foot

\begin{abstract}
Microbiological stability is an important requirement to the medicines developed. In order to prevent microbial contamination of medicines it is necessary to use effective antimicrobial preservatives or active substances with a high preservative effect. Tea tree oil (Melaleuca alternifolia Maid) is a promising antimicrobial substance in development of drugs for use in the diabetic foot syndrom. The microbiological study of the cream with a-lipoic acid, urea, and tea tree oil developed for use in the diabetic foot syndrome has been carried out. The study of the preservative action efficiency of tea tree oil was conducted according to the method of the SPhU. The criterion for efficiency evaluation of the preservative action of the samples under research was decrease of the number of viable cells of microorganisms in the medicines for the certain periods of time after inoculation. The data obtained have shown that the test samples with different concentrations of tea tree oil provide the antimicrobial effect in relation to all test strains of the microorganisms used. The number of microorganisms decreased during storage. It has been found that introduction of tea tree essential oil in the concentration of $3 \%$ provides microbiological stability of the medicine developed according to the requirements of the SPhU. By efficiency of its preservative action the essential oil of tea tree meets the requirements of criterion "A" according to the SPhU, and it allows not to add extra preservatives to the cream developed.
\end{abstract}

Infectious inflammatory skin disease in patients with diabetes mellitus can be attributed to its non-specific complications. As a result of neuropathy, micro- and macroangiopathy there are disorders of innervation and microcirculation, redox processes change, and it leads to decrease of local and general immunity. On the skin surface of patients with diabetes approximately 2-3 times more microorganisms than in healthy people, including pathogenic and opportunistic microorganisms, are usually detected. It is associated with the decreased bactericidal activity of the skin in patients with diabetes that aggravates specific complications, such as the diabetic foot syndrome [8, 12].

An essential tea tree oil (Melaleuca alternifolia Maid) is a promising antimicrobial substance in development of drugs for use in the diabetic foot syndrom. Numerous investigations confirm the healing properties of tea tree oil in parasitic and fungal skin diseases, acute necrosis of diabetes, as well as other infectious diseases (dental, otorhinolaryngological, gynecological diseases) $[6,7$, 9-11, 13-16]. Tea tree oil can be also used as a preservative $[1,4]$.

Microbiological stability is an important requirement to the medicines developed. Microbiological stability control is particularly important for soft drugs based on the emulsion, which are exposed to contamination.

The aim of research was to investigate the microbiological purity of the cream with $\alpha$-lipoic acid, urea, and tea tree oil developed for use in the diabetic foot syndrome [2].

\section{Materials and Methods}

The study of efficiency of tea tree oil was carried out on clinical strains of Pseudomonas aeruginosa ATCC 9027 , Staphylococcus aureus ATCC 6538, Candida albicans ATCC 10231 by the method 5.1.3 of the State Pharmacopoeia of Ukraine (SPhU) for medicinal products for topical use [3]. For analysis six samples of the cream with different concentrations of tea tree oil $(1 \%, 2 \%, 3 \%, 4 \%, 5 \%)$ and the cream sample without essential oil were prepared.

The samples were inoculated with a suspension of one of the test microorganisms selected. The inoculated samples of the cream were kept at a temperature from $20^{\circ} \mathrm{C}$ to $25^{\circ} \mathrm{C}$ and protected from light. After contamination by microorganisms at certain time intervals (days $2,7,14,28$ ) the samples were placed on nutrient media to determine the viable cells count.

Dense nutrient media (Sabouraud's medium, egg yolk high salt agar culture medium, nutrient agar, thioglycollate medium) used in the research were standard. They were prepared in accordance with the manufacturer's requirements (the amount of powder per litre, $\mathrm{pH}$, autoclaving conditions, etc.). Each batch used in the experiment was tested on the growth quality according to regulatory documents (inoculation of test strains of microorganisms taking into account 24-120-hour growth of the corresponding strains). 
Efficiency of the antimicrobial preservative action of the cream containing 3\% tea tree oil

\begin{tabular}{|c|c|c|c|c|c|}
\hline \multirow[b]{2}{*}{ Exposition } & \multicolumn{2}{|c|}{ Requirements of the SPhU } & \multicolumn{3}{|c|}{$\begin{array}{c}\text { Number of microorganisms (CFU/ml) } \\
* \text { Ig of reduction }\end{array}$} \\
\hline & $\begin{array}{l}\text { the bacterial } \\
\text { count CFU/ml, } \\
\text { lg of reduction }\end{array}$ & $\begin{array}{l}\text { the number } \\
\text { of fungi CFU/ml, } \\
\text { lg of reduction }\end{array}$ & $\begin{array}{c}\text { Staphylococcus } \\
\text { aureus } \\
\text { ATCC } 6538\end{array}$ & $\begin{array}{c}\text { Pseudomonas } \\
\text { aeruginosa } \\
\text { ATCC } 9027\end{array}$ & $\begin{array}{c}\text { Candida albicans } \\
\text { ATCC } 885 / 653\end{array}$ \\
\hline Microbial load & $10^{6}$ & $10^{6}$ & $\begin{array}{l}2 \times 10^{5} \\
* 5.30 \\
\end{array}$ & $\begin{array}{c}2.5 \times 10^{5} \\
* 5.39\end{array}$ & $\begin{array}{c}2.5 \times 10^{5} \\
* 5.39\end{array}$ \\
\hline $\begin{array}{l}\text { Primary } \\
\text { inoculation, lg }\end{array}$ & - & - & $\begin{array}{c}5.1 \times 10^{4} \\
{ }^{*} 0.60\end{array}$ & $\begin{array}{c}5.1 \times 10^{4} \\
{ }^{*} 0.69\end{array}$ & $\begin{array}{c}5.1 \times 10^{4} \\
* 0.69\end{array}$ \\
\hline 2 days & 2.00 & - & $\begin{array}{c}2.3 \times 10^{2} \\
* 2.94\end{array}$ & $\begin{array}{l}2.5 \times 10^{3} \\
* 2.00\end{array}$ & $\begin{array}{c}2.7 \times 10^{3} \\
* 1.96\end{array}$ \\
\hline 7 days & 3.00 & - & $\mathrm{NI}$ & $\begin{array}{c}0.9 \times 10^{2} \\
* 3.44\end{array}$ & $\begin{array}{l}1.1 \times 10^{2} \\
* 3.35\end{array}$ \\
\hline 14 days & - & 2 & $\mathrm{NI}$ & $\mathrm{NI}$ & $\begin{array}{l}0.3 \times 10^{2} \\
* 3.92\end{array}$ \\
\hline 28 days & NR & NR & $\mathrm{NI}$ & $\mathrm{NI}$ & $\mathrm{NI}$ \\
\hline
\end{tabular}

Notes: NR - the number of viable cells of microorganisms or fungi does not rise; $\mathrm{NI}$ - viable cells of microorganisms or fungi are not isolated.

The criterion for efficiency evaluation was reduction of the number of viable cell colonies of microorganisms for a certain period after contamination [3]. In accordance with the requirements of the SPhU in medicinal products for topical application logarithms of reduction in viable bacterial colonies in 2 days should be not less than 2 , in 7 days - not less than 3 , and further the number of viable bacterial cells should not increase. Logarithms of reduction of the number of fungi viable cells in 14 days should be not less than 2 . These values correspond to criterion " $\mathrm{A}$ ". In accordance with criterion " $\mathrm{B}$ " in formulations for topical application logarithms of reduction in viable bacterial colonies in 14 days must be at least 3 , and further the number of viable colonies should not increase. Logarithms of reduction of viable fungi in 14 days should be not less than 1 and there is no further increase. The presence of viable cells of microorganisms and fungi on the 28-th day of studies indicate that the drug does not meet criteria "A" or "B" and does not meet the requirements of the SPhU.

\section{Results and Discussion}

The data obtained experimentally show that the test samples with tea tree oil exhibit the antimicrobial activity against all the microorganisms used. The number of microorganisms during storage decreased (Tab. 1).

The data obtained showed that the samples with the concentration of tea tree oil of $3 \%, 4 \%$ and $5 \%$ on day 2 had logarithms of reduction for bacteria more than 2 , and in 7 days - more than 3 . On day 14 and 28 of incubation microorganisms were not registered. Logarithms

Table 2

Efficiency of the antimicrobial preservative action of the cream without tea tree oil

\begin{tabular}{|c|c|c|c|c|c|}
\hline \multirow[b]{2}{*}{ Exposition } & \multicolumn{2}{|c|}{ Requirements of the SPhU } & \multicolumn{3}{|c|}{$\begin{array}{c}\text { Number of microorganisms (CFU/ml) } \\
{ }^{*} \text { Ig of reduction }\end{array}$} \\
\hline & $\begin{array}{l}\text { the bacterial } \\
\text { count CFU/ml, } \\
\text { lg of reduction }\end{array}$ & $\begin{array}{c}\text { the number } \\
\text { of fungi CFU/ml, } \\
\text { lg of reduction }\end{array}$ & $\begin{array}{c}\text { Staphylococcus } \\
\text { aureus } \\
\text { ATCC } 6538\end{array}$ & $\begin{array}{c}\text { Pseudomonas } \\
\text { aeruginosa } \\
\text { ATCC } 9027\end{array}$ & $\begin{array}{l}\text { Candida albicans } \\
\text { ATCC } 885 / 653\end{array}$ \\
\hline Microbial load & $10^{6}$ & $10^{6}$ & $\begin{array}{l}2 \times 10^{5} \\
* 5.30\end{array}$ & $\begin{array}{c}2.5 \times 10^{5} \\
* 5.39\end{array}$ & $\begin{array}{l}2.5 \times 10^{5} \\
* 5.39\end{array}$ \\
\hline $\begin{array}{l}\text { Primary } \\
\text { inoculation, lg }\end{array}$ & - & - & $\begin{array}{l}5.1 \times 10^{4} \\
{ }^{*} 0.60 \\
\end{array}$ & $\begin{array}{c}5.1 \times 10^{4} \\
* 0.69\end{array}$ & $\begin{array}{l}5.3 \times 10^{4} \\
{ }^{*} 0.67\end{array}$ \\
\hline 2 days & 2 & - & $\begin{array}{l}4.3 \times 10^{3} \\
* 1.67\end{array}$ & $\begin{array}{l}4.9 \times 10^{3} \\
* 1.70\end{array}$ & $\begin{array}{l}2.4 \times 10^{4} \\
* 1.01\end{array}$ \\
\hline 7 days & 3 & - & $\begin{array}{c}1.5 \times 10^{2} \\
* 3.13\end{array}$ & $\begin{array}{c}2.1 \times 10^{2} \\
* 3.07\end{array}$ & $\begin{array}{c}3.1 \times 10^{3} \\
* 1.90\end{array}$ \\
\hline 14 days & - & 2 & $\mathrm{NI}$ & $\mathrm{NI}$ & $\begin{array}{l}0.9 \times 10^{2} \\
* 3.44\end{array}$ \\
\hline 28 days & NR & NR & $\mathrm{NI}$ & $\mathrm{NI}$ & $\begin{array}{c}0.2 \times 10^{2} \\
* 4.09 \\
\text { NR }\end{array}$ \\
\hline
\end{tabular}

Notes: $\mathrm{NR}$ - the number of viable cells of microorganisms or fungi does not rise; $\mathrm{NI}$ - viable cells of microorganisms or fungi are not isolated. 
of the viable fungal cells number after 14 days of cultivation were more than 3 . Further fungal cells were not isolated. It indicates that these samples correspond to the efficiency criterion " $\mathrm{A}$ ".

For samples with the concentration of tea tree oil of $1 \%$ and $2 \%$ logarithms of reduction for bacteria were less than 2 on the $2^{\text {nd }}$ day; in 7 days they were less than 3. In 14 days logarithms of reduction for bacteria and fungi were more than 3 . The logarithm of viable fungal cells after 28 days of cultivation did not increase, but single cells continued to register. This indicates that the samples satisfy the efficiency criterion "B" according to the requirements of the SPhU.

It should be noted that decrease in the number of viable organisms was also observed in the sample of the cream without tea tree oil comparing to the initial microbial load (Table 2). After 28 days of cultivation single fungal cells were registered. The sample corresponds to the criterion of efficiency "B"; it can be associated with the low value of $\mathrm{pH}(5.0-5.5)$ due to introduction of $\alpha$-lipoic acid and another active component (urea) $[5,12]$.

It has been found that three of the six samples studied correspond to the criterion of efficiency " $\mathrm{A}$ " in ac- cordance with the requirements of the $\mathrm{SPhU}$ (the cream with concentrations of essential tea tree oil of $3 \%, 4 \%$ and 5\%), and another three samples meet criterion "B" (the cream without the essential oil, the sample of the cream with $1 \%, 2 \%$ concentration of tea tree oil).

Thus, inroduction of $3 \%$ tea tree oil provides the microbiological stability of the composition according to the requirements of the $\mathrm{SPhU}$. To increase the concentration $(4 \%, 5 \%)$ is not expedient from the economic point of view. The results obtained in the research indicate that addition of extra preservatives are not required. As a preservative it is advisable to use tea tree oil in the concentration of $3 \%$.

\section{CONCLUSIONS}

Microbiological studies of the cream with $\alpha$-lipoic acid, urea, and tea tree oil have been carried out. It has been found that introduction of tea tree essential oil (Melaleuca alternifolia Maid) in the concentration of $3 \%$ provides microbiological stability of the formulation developed; and therefore, introduction of additional preservatives is not required. By efficiency of its preservative action the cream meets the requirements of criterion "A" according to the State Pharmacopoeia of Ukraine.

\section{REFERENCES}

1. Беликов О.Е., Пучкова Т.В. Консерванты в косметике и средствах гигиеньл. - М.: Косметика и медицина: ИД, 2003. - 250 с.

2. Гончарова А.А., Баранова И.И. // «Актуальные вопросы науки, образования и производства в фармаиии»: сбор. матер. науч.-практ. конф., 2013г., г. Ташкент. - С. 389-391.

3. Державна фармакопея України / Державне підприємство «Науково-експертний фармакопейний ичентр». 1 вид. - X.: РIPEГ, 2001. - 556 c.

4. Елисаветченко А.В. // Сырье и упаковка. - 2005. - №9. - C. 11-12.

5. Коваленко С.М. // «Медицинская наука и практика ХХІ века»: сбор. матер. Международной науч.-практ. конф., 07-08 сентября 2012 г., г. Киев. - С. 84-85.

6. Лебединецьь О.В., Стрілец̧ь О.П., Баранова I.І. // Клінічна фармація - 2010. - T. 14, №4. - С. 31 -33.

7. Ярних Т.Г., Левачкова Ю.В., Гаркавичева О.А. // Фітотерапія. - 2011. - №1. - С. 77-79.

8. Bansal V., Kalita J., Misra U.K. // Postgrad. Med. J. - 2006. - Vol. 82. - P. 95-100.

9. Garozzo A., Timpanaro R., Bisignano B. et al. // Lett. in Applied Microbiol. - 2009. - Vol. 49, №6. - P. 806-808.

10. Hammer K.A., Carson C.F., Riley T.V. // J. of Applied Microbiol. - 2003. - Vol. 95, №4. - P. 853-860.

11. Hammer K.A., Carson C.F., Riley T.V. et al. Lipids and Essential Oils as Antimicrobial Agents. - 2011. P. 255-306.

12. Han T., Bai J., Liu W. // Eur. J. Endocrinol. - 2012. - Vol. 167, №4. - P. 465-471.

13. Jenny M. Wilkinson, Heather M.A. Cavanagh // Phytotherapy Res. - 2005. - Vol. 19, №7. - P. 643-646.

14. Lang G., Buchbauer G. // Flavour and Fragrance J. - 2012. - Vol. 27, №1. - P. 13-39.

15. Nader Pazyar, Reza Yaghoobi, Nooshin Bagherani //Intern. J. of Dermatol. - 2013. - Vol. 52, №7. - P. 784-790.

16. Oliva B., Piccirilli E., Ceddia T. et al. // Lett. in Applied Microbiol. - 2003. - Vol. 37, №2. - P. $185-187$.

МІКРОБІОЛОГІЧНІ ДОСЛІДЖЕННЯ КРЕМУ ДЛЯ ЗАСТОСУВАННЯ ПРИ СИНДРОМІ ДІАБЕТИЧНОЇ СТОПИ

А.А.Гончарова, І.І.Баранова, Т.П.Осолодченко

Ключові слова: олія чайного дерева; консервант; мікробіологічні дослідження; мікробіологічна стабільність; діабетична стопа

Важливою вимогою до розроблюваних лікарських препаратів є мікробіологічна стабільність. 3 метою запобігання мікробній контамінації препаратів необхідно використовувати ефективні антимікробні консерванти або діючі речовини з високою консервуючою дією. Перспективною 
антимікробною субстанцією при розробці засобів для застосування при синдромі діабетичної стопи є ефірна олія чайного дерева (Melaleuca alternifolia Maid). Нами було проведено мікробіологічне вивчення розробленого крему з а-ліпоєвою кислотою, сечовиною і олією чайного дерева для застосування при синдромі діабетичної стопи. Дослідження ефективності консервуючої дії ефрірної олії чайного дерева проводилося за методикою ДФУ. Критерієм оцінки ефективності консервуючої дії досліджуваних зразків було зниження числа життєздатних клітин мікроорганізмів у препаратах за певний період часу після їх інокуляції. Отримані дані показали, що досліджувані зразки з різною концентрацією олії чайного дерева проявляють антимікробну дію по відношенню до всіх використаних тест-штамів мікроорганізмів. Кількість життєздатних клітин бактерій та грибів зменшувалася в процесі зберігання. Встановлено, що введення олії чайного дерева в концентрації 3\% забезпечує мікробіологічну стабільність препарату згідно з вимогами ДФУ. Ефрірна олія чайного дерева в концентрації 3\% за ефективністю консервуючої дії відповідає вимогам критерію «А» ДФУ, що дозволяє не включати до складу розроблюваного препарату додаткові консерванти.

\section{МИКРОБИОЛОГИЧЕСКИЕ ИССЛЕДОВАНИЯ КРЕМА ДЛЯ ПРИМЕНЕНИЯ ПРИ СИНДРОМЕ ДИАБЕТИЧЕСКОЙ СТОПЫ А.А.Гончарова, И.И.Баранова, Т.П.Осолодченко}

Ключевые слова: масло чайного дерева; консервант; микробиологические исследования; микробиологическая стабильность; диабетическая стопа

Важным требованием к разрабатываемым лекарственным препаратам является микробиологическая стабильность. С целью предотвращения микробной контаминации препаратов необходимо использовать эффрективные антимикробные консерванты либо действующие вещества с высоким консервирующим действием. Перспективной антимикробной субстанцией при разработке средств для применения при синдроме диабетической стопы является эфрирное масло чайного дерева (Melaleuca alternifolia Maid). Нами было проведено микробиологическое изучение разработанного крема с $\alpha$-липоевой кислотой, мочевиной и маслом чайного дерева для применения при синдроме диабетической стопы. Исследование эфрфективности консервирующего действия эфирного масла чайного дерева проводилось по методике ГФУ. Критерием оценки эффективности консервирующего действия исследуемых образцов было снижение числа жизнеспособных клеток микроорганизмов в препаратах за определенный период времени после их инокуляции. Полученные данные показали, что исследуемые образцы с различной концентрацией эфирного масла чайного дерева проявляют противомикробное действие по отношению ко всем использованным тест-штаммам микроорганизмов. Количество жизнеспособных клеток бактерий и грибов уменьшалось 8 процессе хранения. Установлено, что введение масла чайного дерева в концентрации $3 \%$ обеспечивает микробиологическую стабильность препарата согласно требованиям ГФУ. Эфрирное масло чайного дерева в концентрации 3\% по эфффективности консервирующего действия отвечает требованиям критерия «А»ГФУ, что позволяет не включать в состав разрабатываемого препарата дополнительные консерванты. 